\title{
DISSERTAÇÕES
}

\section{Lições de Catende: um estudo sobre a luta pela construção de uma autogestão na Zona da Mata Sul de Pernambuco na década de 1990}

Fernando Kleiman

Curso: Mestrado em Sociologia

Data da defesa: $1^{\circ}$ de junho de 2006

Orientadora: Prof $^{\mathrm{a}} \mathrm{Dr}^{\mathrm{a}}$ Christiane Girard Ferreira Nunes

\section{Resumo}

O objetivo desta pesquisa foi compreender o processo de recuperação da falida Usina Catende por seus trabalhadores e trabalhadoras. Localizada na Zona da Mata Sul de Pernambuco, essa usina chegou a ser o maior complexo de produção sucro-alcooleira da América Latina. A crise econômica da década de 1980 e a má gestão do empreendimento pelos seus usineiros levaram a empresa a uma crise financeira de grandes proporções. Devedora do Estado e dos seus trabalhadores e trabalhadoras, em 1993 ela demitiu 2.300 funcionários, alegando falta de recursos. Nesse mesmo ano, a rica festa de reveillon de seus donos, em Recife, ganha as primeiras páginas dos jornais.

Os trabalhadores e as trabalhadoras, revoltados com a situação, foram mobilizados pelos sindicatos em uma greve que durou 19 dias. O resultado foi o início de uma cogestão que, ao longo do tempo, torna-se cada vez mais autogestionária. Esse processo de luta foi analisado em três dimensões principais: uma disputa judicial contra fraudes, uma disputa de mercado com tradings internacionais e uma disputa política com complexas redes de apoios e de ataques de 
partidos e grupos políticos. Essas dimensões estão sintetizadas no campo que chamamos de gestão da empresa, onde aparece um outro conflito: o das velhas práticas (oriundas da antiga Usina Catende patronal) com as novas (mecanismos de participação do Projeto Harmonia-Catende).

Concluímos que a autogestão do Projeto Harmonia-Catende foi construída por um conjunto de soluções não planejadas, que visavam responder à luta por direitos daqueles sujeitos. Na raiz dessas soluções encontra-se a formação de movimentos sociais e sindicais que se desenvolveram naquela região, com o apoio da Igreja.

Palavras-chave: autogestão, economia solidária, socialismo, capitalismo, sindicalismo rural, movimentos sociais, Zona da Mata, Pernambuco

\title{
Infra-Estrutura de Chaves Públicas brasileira (ICP-Brasil) e a formação do Estado Eletrônico
}

\author{
Marcello Cavalcanti Barra
}

Curso: Mestrado em Sociologia

Data da defesa: 28 de agosto de 2006

Orientadora: $\operatorname{Prof}^{\mathrm{a}} \mathrm{Dr}^{\mathrm{a}}$ Fernanda Antonia da Fonseca Sobral

\section{Resumo}

Partiu-se da seguinte pergunta: como foi possível surgir o governo eletrônico? Para buscar respondê-la, recorreu-se a um estudo de caso. Pertencente ao campo da Sociologia da Ciência 